\title{
WestVirginiaUniversity
}

THE RESEARCH REPOSITORY @ WVU

Graduate Theses, Dissertations, and Problem Reports

2010

\section{The Ku Klux Klan's portrayal of African Americans in mass media technology}

Heather R. Sager

West Virginia University

Follow this and additional works at: https://researchrepository.wvu.edu/etd

\section{Recommended Citation}

Sager, Heather R., "The Ku Klux Klan's portrayal of African Americans in mass media technology" (2010). Graduate Theses, Dissertations, and Problem Reports. 3002.

https://researchrepository.wvu.edu/etd/3002

This Thesis is protected by copyright and/or related rights. It has been brought to you by the The Research Repository @ WVU with permission from the rights-holder(s). You are free to use this Thesis in any way that is permitted by the copyright and related rights legislation that applies to your use. For other uses you must obtain permission from the rights-holder(s) directly, unless additional rights are indicated by a Creative Commons license in the record and/ or on the work itself. This Thesis has been accepted for inclusion in WVU Graduate Theses, Dissertations, and Problem Reports collection by an authorized administrator of The Research Repository @ WVU. For more information, please contact researchrepository@mail.wvu.edu. 
The Ku Klux Klan’s Portrayal of African Americans in Mass Media Technology

Heather R. Sager

Thesis submitted to the Perley Isaac Reed School of Journalism at West Virginia University in partial fulfillment

of the requirements for the degree of

Master of Science in Journalism

Steven Urbanski, Ph.D., Chair

Jan Boyles, M.S.J

Tori Arthur, M.S.J

Staci Gillard-Matthews, Ph.D.

Department of Journalism

Morgantown, WV

2010

Key Words: Ku Klux Klan; African Americans; Mass Media Technology; Hate Websites; Racism.

Copyright Heather R. Sager 2010 


\begin{abstract}
The Ku Klux Klan’s Portrayal of African Americans in Mass Media Technology
\end{abstract}

\author{
Heather R. Sager
}

The White supremacy group, the Ku Klux Klan was formed in 1866, after the end of the Civil War, in the small town of Pulaski, TN, by six ex-Confederate soldiers. Over the last 143 years the Klan has tried to take full advantage of the media in order to reach the largest audience possible to make its voice heard and spread its ideologies of hate towards African Americans and other minority groups. This study focuses on the similarities and differences in the Klan's portrayal of African Americans between two great technological advances used by the Klan motion pictures from the twentieth century and Internet websites from the twenty-first century. The study also takes into account the changes and advancements that have taken place in American society culturally that can aid in the explanation of the similarities and differences that exist in the Klan's portrayal of African Americans in the mass media in order to justify the organization and use of recruitment.

The study was conducted using a qualitative content analysis and guided by the cultural approach to organizations theory, as well as semiotics. The sample included The Birth of a Nation, The Toll of Justice, www.kkk.com, www.kkkk.net.

The results of this study indicate that the Ku Klux Klan's portrayal of African Americans in its media propaganda have not changed significantly from the twentieth century to the current time. The two films and two websites mirror each other in that one of each type of medium was found to be more overtly racist than the other of the same medium. Both mediums place great emphasis on the group's denouncement of interracial romantic relationships, as well as African Americans being less intelligent and humane than whites. The biggest difference found was that the films rely heavily on pointing out the physical appearance of African Americans, while the websites focus more on "facts and statistics".

The findings of this study would suggests that despite many claims that American society has taken great strides in accepting minorities and making changes that some aspects of our culture never change. Humans will always be afraid of losing power over their own lives, including their land, their family, their jobs and money, and even their respect as human being. This fear is especially strong when the loss may be caused by someone presumed to be less deserving than them. The Ku Klux Klan has continued to spin the same web for centuries to build a white supremacist culture based on fear and power. It has moved from print, to film, and in current time to the Internet, which in itself spins a web of reality created by the user connecting anything he or she wishes, and in the Klan's case a world wide web of hatred and discrimination against African Americans and other minorities. 


\section{ACKNOWLEDGEMENTS}

Thank you to my committee chair and other members for all their guidance and support through this entire process. Without anyone of them this project would be the success it is. Thank you also to the University of North Carolina for the use of their copy of The Toll of Justice. I would like to thank all my family and friends as well, for their love and support throughout my college career. I never would have made it without them! 


\section{TABLE OF CONTENTS}

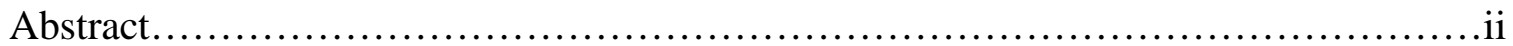

Acknowledgements................................................................ii

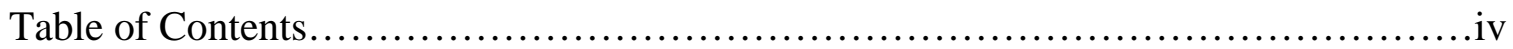

Introduction.........................................................................

CHAPTER I: Review of Literature and Preliminary Research........................2

The Ku Klux Klan in Early Print Media........................................2

Moving towards New Technology: The Klan and Motion Pictures..................

New Media in the twenty-first Century: The Klan and the Internet.................5

Recent Internet use for Klan recruitment..................................6

CHAPTER II: Theory.......................................................

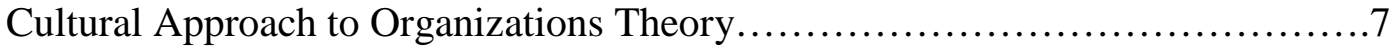

Semiotics.................................................................

CHAPTER III: Research questions, sample, and method..........................8

Research questions...................................................... 8

Sample............................................................8

Method.................................................................. 9

CHAPTER IV: Results and Implications........................................

Films.................................................................. 10

Websites................................................................21

CHAPTER V: Summary and Conclusion........................................26

Prime Differences.....................................................26

The Thread that Completes the Web......................................28

CHAPTER VI: Closing Thoughts and Recommendations........................29

References.....................................................................

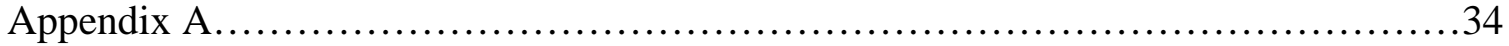

Analysis of Films Code Sheet........................................... 35

Appendix B...............................................................47

Analysis of Websites Code Sheet.........................................48 


\section{Introduction}

The White supremacy group, the Ku Klux Klan was formed in 1866, after the end of the Civil War, in the small town of Pulaski, TN, by six ex-Confederate soldiers. General Nathan Bedford formed the Klan in hopes to "overthrow the Reconstruction Republican state governments and enforce the subordination of the newly freed black people” (Chalmers, 2003, p.1). Over the last 143 years the Klan has tried to take full advantage of the media in order to reach the largest audience possible to make its voice heard and spread its ideologies of hate towards African Americans and other minority groups. These media outlets have included such means as printed material, radio, films, and the Internet.

As mass media technology has progressed, bringing endless possibilities of exploration into the world with a simple click of a mouse, American society has become more diverse and aware of the differences that make the United States a free society. While tolerance for the Klan's activities and hate-filled mantra have somewhat declined in the twenty-first century the Klan is still alive and active in many areas today, according to studies conducted by the Southern Poverty Law Center (2008).

In the 1998 documentary The Ku Klux Klan: A Secret History, the narrator opens by saying "times have changed, the message [of the Klan] has not" (Brummel, 1998). Though this statement may ring true in many aspects of the Klan, it would be unlikely that given the time that has passed since the group's formation, and the advances and changes in our society over the last 143 years that the organization's portrayal of African Americans in its recruitment propaganda has not changed at all. Therefore, this study aimed at determining the similarities and differences in the Klan's portrayal of African Americans between two great technological advances used by the Klan - motion pictures from the twentieth century and Internet websites from the twenty-first century. The study also takes into account the changes and advancements that have taken place in American society culturally that can aid in the explanation of the similarities and differences that exist in the Klan's portrayal of African Americans in the mass media in order to justify the organization and use of recruitment.

To this date, there is no research on how the Ku Klux Klan has utilized new technology in two different centuries - the early twentieth century with motion pictures, and the early twenty-first century with the Internet - or investigated how its portrayal of African Americans has changed with the new media and the changes within American society. By comparing and contrasting how the Klan has represented African Americans in two vastly different time periods in its use of motion pictures verses current websites, there can be a better understanding of how the Klan's message and image has changed with time to keep the organization alive for so many years.

This study examines the implications and inferences that the Klan is making to the audience based on its portrayal of the minority, and how it has changed as society and technology have changed. Countless studies have been conducted on the perception of the audience and the effects of mass media. Most of these studies have concerned themselves with culture of the audience, the experience the media creates for the viewer, and the feelings it provokes. As time has progressed, many studies have taken into consideration the conditions of the time period as well as the producer of the media and the receiver (Nightingale, 1996). This study takes into account the social and cultural background of the time period and what influence it has on the Klan's depiction of African Americans in the media; however, it does not measure the degree of effectiveness that these depictions have on a given audience. 


\section{Chapter I: Review of Literature and Preliminary Research}

\section{The Ku Klux Klan in Early Print Media}

As Dr. Irving Fang (2008) discusses in his book Alphabet to Internet, in the early birth of books and other widespread printed material in the early thirteenth century many people up until this time could not read. As the popularity of printed material grew people longed to read and as literacy grew along with the available reading material. Interests grew and as printing became more prevalent, people quickly learned the power of the printed word. By the twentieth century even the lower class owned books and newspapers and other mass printed materials were becoming widely used. There were fewer illiterate citizens making the sharing of ideas through the media become much easier. The Ku Klux Klan took great interest in using printed media material, both its own and mainstream, to help promote the organization.

The second time the presence of the Ku Klux Klan was strongly felt in the United States, after its formation, began on Thanksgiving night in 1915. William Joseph Simmons (who eventually became the Imperial Wizard, the highest rank in the Klan) proclaimed the arrival of the new Knights of the Ku Klux Klan in Atlanta, Georgia, by setting a large cross on fire that lit the night sky for all to see for miles around (Gerlach, 1992). With racism still strong within American society and the government still struggling to rebuild and gain the support of its nation, the Klan used the society's already present fears of change and immigration to fuel its hatred towards African Americans and justify the need for the organization, putting forth that the minority group must be controlled.

Shortly after Simmons's demonstration he and his Klan enlisted the help of the media in their efforts and signed a contract with the Southern Publicity Association, a marketing company that helped promote right wing organizations of the time. The company presented the Klan to the public as an esteemed and respect organization. Their media associated the Klan with the Red Cross, the Anti-Saloon League (an organization that lobbied for Prohibition), the Salvation Army, and the War Work Council (a organization that provided services to women who were working and service men and their families during WWI). The media outlets of the Southern Publicity Association, mostly newspapers, published articles making connections for the Klan with the venerated organizations and helped its membership to grow to over 100,000 in just a few months (Lay, 2004).

Although the Klan took advantage of being portrayed as a prestigious and morally sound organization in early print media, many branches of the Klan were open with their negative views of African Americans in the press. Simmons and his hundreds-of- thousands of followers printed their own publications and controlled printing sources to feed racist, anti-Jew, and antiCatholic ideas to create a reality of fear and vastly increase their membership (Brummel, 1998). Many newspapers regularly printed Klan-supporting articles, advertisements for rallies and marches, and racist cartoons. In the South during the 1920s, The Kourier-printed an article in which it spoke out against the Communist union organizers in North Carolina. The paper named the Communist party's worst offense as being “their advocacy of 'Negro equality"” (MacLean, 1994, p. 140). The Klan was against the Communist movements because it feared it would end the racial hierarchy it had been fighting to implement. The Klan used the Kourier- as an outlet to infuse fear into citizens of both the blacks and Communists.

One of the largest protested and feared occurrences of the KKK was interracial marriage or sexual relationships between white women and black men. The Klan boasted of protecting the 
white womanhood of America and saving their women from the lustful black savages (as they saw them). Klansmen in the South fought to pass a law to make it a felony for a black man to marry a white woman; however, when these efforts failed it moved to its own tactics. Klan members would leave threatening notes to warn blacks of the consequences of having relations with a white woman in hopes of stopping the marriage, among many other more violent strategies (Gerlach, 2004).

Using the media as best they could to encourage “"the necessity' of these legislative and vigilante efforts” (MacLean, 1994, p. 144) the Klan had newspapers print notices of marriages that were to take place between a black man and white women. These publications presumably served as a tool to make people aware of who was engaging in such activity, in hopes that enough people would come together and protest, terrorize, or even kill the black men that dare smear the name of the supposedly defenseless dames (Gerlach, 2004).

An abundant number of articles frequently ran in the Salt Lake City local press with "Rastus" stories, anti-black cartoons, and racial epithets. One Salt Lake City social club ran an advertisement for its minstrel show at the local LDS ward as "Nigger Night." While other publications, such as the Salt Lake City Tribune, ran lengthy stories projecting racism, much like the story ran concerning "legislative log-rolling" with the headline "Senate Concerned over Nigger in the Woodpile” (Gerlach, 2004 p.127).

With the help of print media the Klan was able to reach a large audience and take full advantage of the opportunities presented by the ever-growing technology. It presented itself as “an interest group peacefully pursuing its goals through conventional political activity” (Wald, 1923, as cited in Moore, 2004 p. 29), “100\% Americanism” (Brummerl, 1998), and a "commitment to charity, chivalry, humanity, justice, and patriotism” (Gerlach, 2004, p.128). The Klan held on to the themes of nationalism and a devotion to purity as it tried to appeal to the average white Christian American to boost their membership and spread the fear of African Americans deeper into society.

\section{Moving towards New Technology: The Klan and Motion Pictures}

The first uprising of the Ku Klux Klan's power in the early 1900s was largely due to the support of national print media in perpetuating even more for of African Americans and believed need for control over them. However, most historians accredit the revival primarily to another form of mass media - the motion picture. Fang (2008) points out that the first audiences of motion pictures came from the massive amount of industrial working class. Though much of the poor of the time consisted of immigrants, most showings were open to whites only. The appeal of sitting in a dark room with strangers to share a common experience of the film after a long and grueling day of work became a very popular form of entertainment very quickly in the early twentieth century. The motion picture showings were cheap and fun and they required very little mental laboring making it accessible to even those that could not read.

The release of David W. Griffith's The Birth of a Nation, in 1915, sold out theaters nationwide and has been called the greatest cinematic achievement of its time. Adapted from Thomas Dixon's 1905 novel The Clansman, the film documented the American Civil War, Reconstruction, and the beginning of the Ku Klux Klan (Brummel, 1998).

Researcher from the University of California, Davis, Dr. Riché Richardson (2002), suggests that although the film was a technological innovation as the first feature-length film ever made, many critics also label it as one of the worst films ever made because of the wave of violence against African Americans in the United States incited in the wake of its release due to the flagrant stereotypes of their identity that the film propagated. With the use of motion pictures 
the Klan could seemingly not only tell society its beliefs about the dangerous African Americans and their need for restraint, it could now show them as well. The film put a face to the subject and disseminated even more fear and hatred of African Americans which promoted the organization even further.

In Atlanta, Georgia, Imperial Wizard Simmons used the film to draw record-breaking crowds of Whites for weeks to cheer on the white-robed crusaders. Seeing the great affect the film had on membership, Simmons routinely showed the film and posted advertisements in the local papers encouraging new members to pledge to the Klan. For millions of Americans who viewed The Birth of a Nation (many of whom were attending their first motion picture) the enduring image of the Invisible Empire would be of the robed and hooded Klansmen who ride to the rescue of the imperiled white heroine” (Lay, 2004, p. 5).

Only five years after The Birth of a Nation was released, in the summer of 1920 the Klan grew nationally, adding 85,000 members. These new members helped the Klan reach its loosely estimated peak of five million members in the middle of the decade. Contributing strongly to this expansion was The Birth of a Nation (Rice, 2008). The National Association for the Advancement of Colored People (NAACP) petitioned the governor of Kansas in 1923 to have The Birth of a Nation banned in the state. The organization contended that the film then was "largely responsible for the present day revival of the Klan" (NAACP, 1923, as cited by Rice, p. 472).

Having gained national acceptance and prominent support, even being viewed by President Woodrow Wilson in the White House, The Birth of a Nation, had an everlasting effect on history. As author of The Fiery Cross, Wyn Craig Wade (1987), exalted "the effect of the film was enormous, it increased hatred towards Blacks, made people believe in the history portrayed, and convinced them Black people needed to be controlled" (Wade, 1987, as cited by Brummel, 1998).

The Klan used two other films in the early peak of cinematic history in the 1920s, The Traitor Within (1923) and The Toll of Justice (1916). The Klan used these films, and other mainstream films to as the organization put it "to counteract the poisonous propaganda circulated by alien enemies who have declared their determination to wipe out the Klan” (Fiery Cross, 1923, as cited by Rice, 2008, p.474). Although the Klan became an avid user of motion pictures in the early 1920s it was highly opposed to and protested many films that it felt made the Klan look bad and ridiculed the American-Protestant way of life, such as Charlie Chaplin's film The Pilgrim (1923).

The Klan was infuriated that the film industry was being ran by mainly Jewish producers who made movies supposedly urging interracial sex (Rice, 2008). To counterbalance such films as The Pilgrim (1923) and Bella Donna (1923), a film produced by a Polish-American that depicted an "Egyptian-Negro man seducing a white woman" (Fiery Cross, 1923 as cited by Rice, 2008); the Klan formed the Cavalier Motion Picture Company in Indiana in 1923. In a Klan published newspaper the group stated, "With eight million students daily, the motion picture ought to be the greatest university in the world” (Searchlight, 1924, as cited by Rice, 2008, p.475). It was clear that the Klan fully realized the potential of film to be a great propaganda tool.

Although the Cavalier Company only released one film, The Traitor Within (1923), the film was widely used by several Klan groups across the country to promote a morally stable and honorable image of the group. It was shown in schools, public theaters, and even churches in a 
number of different towns. The Klan used the film to educate the public on the "true" principles of the organization (Rice, 2008).

Another film The Toll of Justice (1923), produced in coalition with the Klan depicted the organization in much the same light as The Traitor Within. Both films aimed at portraying the Klan as a moral reform group for society, trying to clean up the town by closing down bars, and keeping woman safe. They also showed non-Klan members committing various crimes and then framing the Klan in order to tarnish the group’s image (Rice, 2008). By showing this "set-up” to the public the Klan could presumably free itself from any blame in the acts of violence or negative actions.

After the middle half of the twentieth century few, if any, films were produced in obvious support of the Ku Klux Klan, yet the films that were made were used for years to come, and could in all probability still be used as recruitment tools by White supremacy groups today. The Klan used the innovated technology of motion pictures to promote the organization and exploit new technology for its benefit, "exploring the political agency of film as propaganda” (Rice, 2008, p. 472). The Klan used motion pictures to tell a story about African Americans and tried to create the most unpleasant and fearful picture of the race possible.

\section{New Media in the twenty-first Century: The Klan and the Internet}

The Internet was created in 1969, by the as a means for researchers at various universities to better connect with one another through their computers (Fang, 2008). More than 30 years later, "a four-year-old-child at the start of the twenty-first century playing a game has more computer power at her fingertips than the geniuses at the dawn of the computer era could have imagined” (Fang, 2008, p. 261). Communication media have become a huge part of daily lives. With few laws and control the Internet can open up whole knew worlds of knowledge, connect people across seas, and provide information about the most random of topics within seconds. The great technology can also be used in negative aspects as well, and create any reality the user wants, whether it is true or not.

With access to endless possibilities through the Internet, White Supremacy groups have fully taken advantage of yet another technological advance in mass media in the twenty-first century. In 2001 there were 405 hate group website on the Internet, which was a $10 \%$ increase from the previous year (Adams, 2001). In 2005 the number exceeded 4,000, and the number is no doubt on the rise (Palti, 2005). Adams suggests that the reason websites have become such a popular outlet for hate groups such as the KKK, is due to the anonymity the web offers. One can post blogs or articles send emails, and have their ideas heard by billions, without anyone ever seeing their face or knowing their name (Adams, 2001).

Bostdorff (2004) suggests that a further reason the Internet has become so popular for hate groups it that offers a sense of community and identity. Individuals can visit the site, read the postings, view the usually present visitor counter of the website and feel like they are part of a larger group that shares their thoughts and feelings. Bostdorff (2004) also points out that this sense of being a part of something powerful is highly appealing to teenagers, who are usually struggling with identity and fitting in. Hate group websites offer young, easily influenced individuals a way to feel connected to and accepted by those in powerful positions.

A study conducted by Weatherby and Scoggins (2005) found that many hate groups' Internet sites did not use racial epithets or outright racism in hopes of appearing more acceptable and having a cleaner image. The sites would instead use terms such as "white pride” and provide stories about Blacks committing hate crimes against Whites, trying to make their assertions "look well-researched and scholarly” (Weatherby and Scroggins, p. 22). Weatherby and Scroggins 
state in their analysis of the Imperial Klan of America website, that there were only three instances of overtly racist or offensive material and thus the group is making "a distinct effort to separate themselves from their menacing past” (p. 22).

A further study of hate group websites performed by Palmer and Duffy (2001) concluded that although many websites strayed away from outright racism, they turned the tables and painted minorities as being racist towards Whites. In the same study, the researchers found that the major themes used on the Ku Klux Klan website they reviewed, were honor, seeking a better future, and a heroic rescue by courageous men to save the White future (p. 15). These types of themes are similar to those used earlier in Klan's history.

One technique that may be overlooked as a propaganda tool in the Klan's websites is humor. Billig's (2001) study on White Supremacy websites primarily dedicated to “jokes” and "humor" based on racist stereotypes, showed that most of the contributors to the sites promote themselves as "not real life racists" and state that you "must have a sense of humor" (p. 15). With claims such as these, many people can be easily pulled into the ideologies of the groups in thinking that they are "only joking around.” As Billig points out, however, these statements are no longer a funny joke, but hatred and pure racism. By using the phrase "just a joke,” these sites can shield themselves from any negativity or backlash and attempt to make the message more socially acceptable (p. 6). Much like the community and identity theme Bostdorff (2004) presented, the idea of using jokes and humorous cartoons appeals to young people and gives them a reason to visit the White supremacy websites.

\section{Recent Internet use for Klan recruitment}

A prime example of how the Klan has recently used the Internet for recruitment came in 2008 in Covington, Louisiana. A group of Klan members lured a young woman from Oklahoma via the Internet to join the organization. During the woman's initiation ceremony she changed her mind and wanted to leave and she was shot to death by one of the Klan members. The Klan then set the wooded area on fire where they were meeting in hopes of covering up the crime. This incident is just one case in many that demonstrates how easily individuals can be persuaded by the Klan through the Internet (Donahue, 2008).

Whatever the underlying theme used or purpose of the websites used by the Ku Klux Klan, the Internet is certainly useful propaganda tool for the organization and easy way to depict an unpleasant representation of African Americans. The easy access and anonymity of the web offers a packaged agenda to a vast audience that may not otherwise be exposed to the message (Palmer \& Duffy, 2001). Like the film industry in the early twentieth century, the Internet has provided great opportunities for the Klan to disseminate its message of hate against African Americans in the twenty-first century.

No research could be found on comparing and contrasting the way the Klan used these two technologies, and how they were used to depict Africans Americans. By uncovering the different portrayals of African Americans used to recruit members and sympathizers of the Klan in two different time periods and providing explanations of the similarities and differences in depictions based on the cultural and societal makeup of the time, there can be a better understanding of how stereotypes of African Americans have changed from one century to the next; as well as what ideologies the Klan have used to keep the organization going. By understanding what types of ideas and depictions are being used to fuel racism, there can perhaps be an improved education for the media and society in stopping the perpetuation of the negative. 


\section{Chapter II: Theory}

\section{Cultural Approach to Organizations Theory}

The Cultural Approach to Organizations Theory (CAOT) is a contemporary theory in the field of mass media and communications. The theory was first established by Clifford Geertz in the early 1970s. Geertz describes the theory by stating that the concept of culture is semiotic and "man is an animal suspended in webs of significance he himself has spun" and culture is the webs that are spun (p. 5). He also points out that the analysis of these webs, or culture, is not an experimental science in search of facts but an interpretative one in search of meanings.

This theory can easily be applied to the research of the content of films and Internet websites used by the Ku Klux Klan as propaganda. The Klan is an organization and can be classified as a subculture on its own. By using different media outlets and various resources, such as the films and websites, the Klan can spin whatever kind of web it feels will appeal to the public and build its own seemingly acceptable culture based on its own meanings of reality.

In a study involving corporate cultures and their use of space using the CAOT, Mars (2008) found that individuals involved in a group for a collective purpose, such as an organization or subculture, will act based on the allegiance of the group and their ideals, rather than their own wishes and personal history or background (p. 187). In applying these findings to the Klan, the association can be made that members of the Klan will part take in racist thoughts and/or actions based on their allegiance to the group, even though they may personally believe it is wrong. A difference, however, between the corporate cultures and the Klan is that members of the Klan may take part in thoughts or activities they do not believe in based on the fact that the consequences of not doing so could be a matter of life or death.

Mars' (2008) study separates organizations or cultures into categories, and defines them based on how they are organized. Using CAOT he states "tell me how you are organized and I am able to allocate you to cultural archetype and deduce your values and attitudes and the kind of behaviors they sustain and justify" (p. 189). It can be assumed that Mars would classify the Klan as a Pyramid archetype, which is one that is concerned with procedures, respect for ranks and authority, tradition and ritual to protect the organization, defensive loyalty to the group, and the sacrifice of individuals to defend the group's interest. This type of group also distinguished very heavily between insiders and outsiders, and has a strong emphasis on symbols, ceremony, and extending its rankings of power to encompass the world (p. 194). These inferences about the Klan could help society understand the organization's need for propaganda and the various techniques and themes used in their propaganda to disseminate hate towards African Americans.

In a study using a variation of this theory, Simon Frith (1996) uses the metaphor of music to explain how one's consumption of media can define his or her culture. He states, "The issue is not how a particular piece of music or a performance reflects the people, but how it produces them, how it creates and constructs an experience” (p.109). Music in this sense can be replaced with other mediums of entertainment, such as film or the Internet. By interpreting the content of the films and Internet websites used by the Klan with this theory in mind it will help determine how the media can produce a certain experience for the viewer as well as a certain perception of the group's identity and subculture and how it can influence the user of the media.

Although this theory suggests that motion pictures and Internet websites can affect the user's sense of reality and perception of society and create a culture, as with their ideas about African Americans, there is another side to be considered. The underlying culture and society in which the person is in has already influenced the production of the film or website, and they 
were created based on the perceived ideas and views of the currently existing society. Therefore the two go hand-in-hand. Mass media can aid in creating a person's sense of reality and culture, and the media would not have been created if the producer did not see it as a reflection of their culture. The problem arises, however, when the producer gives a false depiction of culture and reality, and the consumer believes it as true, as with the creation of negative stereotypes of African Americans.

\section{Semiotics}

In addition to the Cultural Approach to Organizations Theory, the semiotics theory also played a vital role in this study. Semiotics is described as the science of signs, messages, and their meanings (Danesi, 2004). It seeks to put reasoning and explanation to the signs, symbols, and messages society uses. In this particular study, semiotics pairs with the cultural approach to organizations theory, in that it looks at the different messages the Ku Klux Klan are sending about African Americans in its media, as well as the meaning and implications of the signs and symbols used to send the messages based on the culture in which they are used.

Because semiotics tends to examine signs/symbols based on the culture in which they are being used, this study took into great consideration the time period and society in which the Klan put forth the different images of African Americans and aimed to put meaning to the images based on the given cultural atmosphere. It was also taken into consideration the culture of the Klan itself and the meaning that it is assumed to imply with the given signs and symbols it uses to portray African Americans. The method of semiotics mirrors the CAOT by pointing out the culture in which the signs and symbols are being used, and showing how the meaning of the signs and symbols help define the culture. For example, body language, vocabulary, pop culture, and clothing. In keeping with the theme of the web, semiotics also constructs a linking of the people and culture using the signs and symbols, in the case the Klan; the signs and symbols themselves, and the meaning that the signs and symbols hold. These different parts create a circle of connections, which is much like a web where everything is interrelated.

\section{Chapter III: Research Questions, Sample, and Method}

\section{Research Questions}

Based on the preliminary research of the Ku Klux Klan's use of motion pictures and Internet websites as recruitment tools, the following questions were generated and are addressed in this study.

RQ 1: What are the similarities and differences in the Ku Klux Klan's portrayal of African Americans in films from the early twentieth century and Internet sites from the twenty-first century that promote the Klan and its beliefs?

RQ2: When comparing the early twentieth and twenty-first centuries, what part does political/economic forces, as well as social norms and beliefs, and stereotypes play in explaining the portrayal of African Americans by the Ku Klux Klan in their recruiting propaganda?"

RQ3: What differences and similarities of motion pictures and the Internet can be identified to explain the differences and similarities in the Ku Klux Klan's portrayal of African Americans in recruitment propaganda?

\section{Sample}

In order to examine the Ku Klux Klan's portrayals of African Americans in two different technological eras, two films were first analyzed, The Birth of a Nation (1915) and The Toll of 
Justice (1916). These films were chosen based on preliminary research that found that the Ku Klux Klan heavily used these films as recruitment tools in the early part of the twentieth century. These films were also chosen based on availability since there are very few surviving copies of any early 1900s films used by the Klan.

To compare and contrast the depictions of African Americans in the films to the most current technological advances in mass media, the Internet, two websites that were promoters of the Klan were then analyzed. The sites were: www.kkk.com which is the first link to reach www.kkk.bz (will be used as one site), and www.kkkk.net. The sites were chosen based on their rate of appearance in performing a Google search of different variations of the phrase "Ku Klux Klan," "KKK," and "Knight of the Ku Klux Klan," as well as past research on Internet hate group websites conducted by Weatherby and Scroggins (2005). Their findings suggest that these groups use different techniques that hate websites use to appear less racist. Similarly, Palmer and Duffy (2001) suggest that the rhetoric in hate websites is trying to seem less offensive. The two sites were also chosen after preliminary research found that they provided the most content to be analyzed out of four selected websites.

\section{Method}

To compare and contrast the Klan's portrayal of African Americans in two different technological advances, film and the Internet, a qualitative content analysis was conducted. Unlike a quantitative content analysis that focuses on the number of times something specific occurs, a qualitative analysis puts the emphasis on "capturing definitions, meanings, process, and types” (Altheide, 1996). This study examined the types of portrayal presented and the various tactics used to create meaning and definition of African Americans in the Ku Klux Klan's films and websites in different time periods.

To better describe the purpose of a qualitative content analysis Hansen, Negrine, and Newbold (1998) assert that this type of method allows the researcher to "be able to say something about the messages, images, representation of texts, and their wider social significance” (p. 95). The end result of a qualitative content analysis is not a set of statistics telling how many times something happened in the text; instead it is a more in-depth definition and explanation of what is happening and the implications. Richardson (2002) used a qualitative content analysis to examine the themes of racism in the films The Birth of a Nation (1915), The Klansman (1967), and O.J. Simpson's murder trial. While Richardson's (2002) study is somewhat different from the one to be conducted, it shows that the findings of a qualitative content analysis are endless, and if the right approach is taken, texts and events can be closely linked together in new and unique ways.

Most of the past and current research involving films is done using one or another variation of a qualitative content analysis. In three previously mentioned articles dealing with the interpretation of film, Rice (2008, 2008a), Richardson (2002), research endeavors were conducted using a qualitative content analysis. In both of Rice's articles he performed in-depth examination of films used by the Ku Klux Klan as well as the advertising for the films in order to better understand how the films were used to promote the Klan.

A qualitative content analysis was also used in the earlier mentioned articles concerning Internet hate websites. Each researcher used his or her own variation and adaptations of a qualitative content analysis to study the messages and themes used in recruitment and dissemination of the Klan's ideologies through the Internet (Billig, 2001), (Bostdorff, 2004), (Weatherby and Scoggins, 2006), and (Palmer and Duffy, 2001). 
In this particular study the two chosen films were viewed and analyzed before the websites. In order to evaluate the Ku Klux Klan's portrayal of African Americans in both forms of media, the depictions of a variety of the different facets in African Americans' lives presented in the films and Internet sites were examined described.

These aspects included:

1. Physical appearance

2. Intelligence level

3. Interactions among other members of their own race

4. Interactions with Whites

5. Holding government positions

The depiction of these various aspects of African Americans' lives within the chosen films and Internet websites were then compared and contrasted with one another in order to define any similarities and differences that may exist between the portrayals of the race in the two media outlets. Based upon the finding of these analyses, as well as additional preliminary research on the social and cultural atmosphere of the early twentieth century when the films were used and the current social and cultural atmosphere, the changes or parallels in the two time periods were identified in order to explain the similarities and differences in the Klan's portrayal of African Americans in its recruitment propaganda. The dissimilarities and resemblance between the two media outlets are also indentified based on preliminary research and applied to the changes or likenesses in the Klan's portrayal of African Americans.

\section{Chapter IV: Results and Implications}

In order to address the Ku Klux Klan's portrayal of African Americans in films used in the twentieth century used for recruitment to the portrayal in current websites and effectively convey the findings of this study and the implications behind them, the three research questions will be addressed in a combined fashion. First, the two films that were analyzed (Birth of $a$ Nation, and The Toll of Justice) will first be presented along with the historical and cultural issues in society at the time of the films' releases, as well as the characteristics of the type of media used, that may lend suggestion to the portrayals and messages that were found, using semiotics. Second, the findings of the analysis of the websites and the inferences of their historical and cultural background of society, and the defining characteristic of the Internet, will then be presented and compared and contrasted to those of the films'. Last, the most prominent similarities and differences found in the Klan's portrayal of African Americans in the films and websites will be discussed.

\section{Films}

\section{The Birth of a Nation}

The analysis of the first film, The Birth of a Nation, found various portrayals of African Americans, that seemed to be nearly all linked together with a few common threads: fear, ignorance, and exaggeration. The opening scene is introduced with the producers stating that they have the "liberty to show the dark side of wrong, that we may illuminate the bright side of virtue" (BON, 1915). It is suggested already to the viewer that dark, or black, equates wrong and evil, and bright meaning whites equates virtue and worthiness. The film, however, tires to defend itself by putting forth that it is "not meant to reflect on any race or people of today" it is merely a "historical interpretation" (BON, 1915). With this specification made, D.W. Griffith and the other producers of the film use their artistic license to create their interpretation of the 
beginning of the Civil War, how each side acted after the end of the war, and the formation of the Ku Klux Klan, and its early activities.

\section{Physical Appearance.}

The physical appearance of the African Americans in the film is both true to life and highly exaggerated. Some of the actors/actresses in the film can be identified as true African Americans; others are obviously white with their skin painted black or a very dark shade of brown. These actors' lips are painted to look very white or red and incredibly large. Their eyes are large and pupils made to appear extremely large and white as well. The film plays into the stereotype that is still common today, that African Americans have large protruding lips and bulging eyes (Wilson, et. al, 2003). If a character is supposed to be a mulatto then he or she is a white actress painted a light shade of brown and has large white pupils and crazed look.

The African American males in the film are usually dressed in raggedy old clothes. Many are shown wearing striped pants or polka dots. Most wear hats and no shoes. The only welldressed African American males are wagon drivers and servants to high-class white families. The makers of the film do their best to make the African Americans appear poor and uncivilized. During the Civil War the males are shown in torn uniforms with their bare chest and arms ballooning out causing them to appear large and beastly.

Whether the African American males in The Birth of a Nation are true African Americans, or the white actors in makeup, they are created to seem almost animal-like with large gaping mouths that frequently curl into a sneer while their bulging eyes look wild and crazed. They normally are depicted hunched over as on the prowl when walking and with their shoulders crunched and angry when sitting.

The makers of the film paint unpleasant and unwelcoming physical picture of African American males. They are large, vile, and bizarre looking. The small details of this portrayal may seem insignificant at first glance, but the fact that two-thirds of a person's messages about who they are and what they stand for is conveyed solely through their body language, including facial expressions and eye contact; physical appearance, and posture (Danesi, 2004) make these small aspects of the depiction very important and would presumably have a large impact on the viewer, whether they were aware of it or not. The film's makers create a world of fear for white viewers with the dangerous, ghastly looking African American male characters that will stay on their mind long after the film ends.

The physical appearances of the female African American characters in The Birth of a Nation are portrayed less scary or intimidating than the males. In fact, they are shown as the nurturing and motherly in most instances. Nearly all the female African Americans in the film are short, large, round women in dresses with aprons. They appear less threatening than the males, but are still highly stereotypical with most being "mammy" looking figures that were characterized by a large African American female with her head wrapped in a bandana wearing a plain dresses, being a dutiful and happy slave. This image was used in many films and advertising early in America and eventually became the "Aunt Jemima” trademark (Wilson, et. al, 2003). Some females are like the males - true African Americans and others are white women painted dark brown or black. The mulatto women are white females painted a very light shade of brown. The younger African American females are shown with their unkempt hair in zany pigtails and flowered dresses with no shoes.

Although the females are friendlier looking than the African American males in the film, they are still seemingly dirty, with missing teeth and messy, wild hair, and tattered mismatched 
clothing. Both the male and female African American depictions are greatly exaggerated in terms or physical appearance. Their skin and facial features were made to appear almost cartoon or animal like.

The cultural approach to organizations theory would suggest that by giving this type of physical depiction of the African Americans, the Klan can begin spinning its web of how the culture of race should be viewed - with fear and hatred. The African American characters in the film don't even have to speak or take any action and the viewers can still see how different and threatening they appear just by their over emphasized facial features, dress, and posture.

During the time of The Birth of a Nation's release World War I had been going on for a year and white Anglo-Saxon Americans' had deep fears of outsiders, immigrants, and anyone who did not look or act like them. It was assumed that if you looked different and acted different you must be a threat to the American way of life (Rice, 2008). Although slavery had long been over for decades, African Americans were still without full equal rights and they became the targets for discrimination. The Ku Klux Klan used the film to put a literal face on America's problems and attempt to show society the Klan's beliefs were justified.

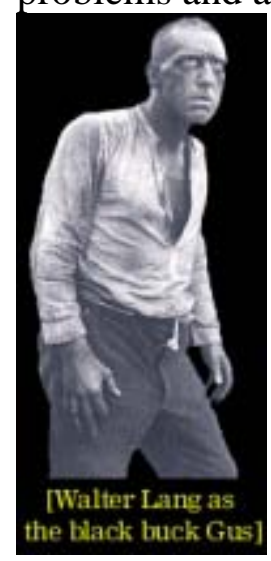

The character Gus from Birth of a Nation. White actor in blackface (Wordpress.com, 2009).

\section{Intelligence Level.}

In The Birth of a Nation both the male and female African Americans' intelligence level is shown to be exceedingly lower than the whites'. Both male and female characters are depicted throughout the film staring crazily and looking bewildered. They smile largely and nod their head eagerly when spoken too but maintain a glazed over, confused look.

When dialogue is shown, regardless of sex of who is being spoken to, the African American are portrayed as having atrocious grammar and lacking even basic English speaking skills. "Ef” is said in place of "if”, "doan” in place of "don't," "mah” for "my”, “ "nuf” in place of "enough”, "sah” for "sir” and "N’of” for "North.” There accent and manner of speaking is exaggerated to make them sound uncivilized and stupid.

Due to the fact that the film is silent, except for the ever-so-stimulating music, viewers cannot actually hear the African American characters speech or words, but the makers of the film flash them enough times through the film to create a clear picture of how simple minded and uneducated they believed the African Americans were. By giving this portrayal of ignorance the Klan can produce for the audience a group of fools who are beneath them and do not possess enough intelligence to even understand when they are being insulted. In presenting this idea to the audience, the Klan convinces the audience that African Americans were too ignorant to even 
classify as on the same human level as whites, making them less deserving of rights and needing to be restricted from interaction within society.

Interaction with Members of Their Own Race.

In the entire three hours of The Birth of a Nation there is only one scene in which two African American females are shown interacting. One is a mulatto servant, and the other a darker skinned servant. The two are shown joking around and being friendly, yet this is the only depiction of females together. This lack of portrayal of African American women together suggests to the audience that African American females were not sociable or shared any type of bond. By leaving depictions out of the women with one another the film portrays their interactions as unimportant and makes them appear less friendly and welcoming as white women.

African American females are shown fewer times with African American males, as well; and the two are never depicted in a loving relationship or family environment. There are only two scenes in the film where African American males and females are depicted being even remotely friendly with one another. One occurs early in the film when one of the main characters in the film, a mulatto man, flirts with a mulatto housemaid. The second scene depicts an African American female dancing wildly and drinking with a group of African American males. Neither scene portrays the relationship between African American males and females positively, and the remaining scenes in the film that depict the two together are highly negative portrayals.

In one of the scenes that depict African American males and females together, a male wagon driver from the North is carrying in his master's bags and an African American female house maid approaches him. Before the wagon driver barely looks at her she curses him with her dialogue shown on the screen: "Yo' northern low down black trash don't try no airs on me" (BON, 1915). She then pushes and kicks the man. A few minutes later they are shown together again and to taunt the women the wagon driver makes flirty eyes at her raising his eyebrows up and down, which infuriates the woman. She hits him until he leaves and then her dialogue shows as, “Den’ free-niggers fu’m de N’of am sho’ crazy!” (BON, 1915).

By giving these depictions of the African American man being somewhat disrespectful to a woman of his race and the woman automatically assuming he is a perverted, northern piece of trash portrays the relationship between the different sexes of the race as very troubled and hostile. The white viewers of the film in the early twentieth century placed extreme value on the bond of family. The depiction of the African American family does not exist in the film, therefore suggesting to the audience that African Americans are not cable of maintaining a loving, respectable family relationship, sending the message that they are less respectable and deserving of love.

The Klan used the lack of positive family portrayals of African Americans in The Birth of a Nation to continue to create a lack of sympathy or understanding in the white audience of the twentieth century minds'. The audience is shown how unloving and disconnected from one another the African Americans were presumed to be, allowing them to remove any human qualities from the race. This put the African Americans almost on the level of wild animals, adding another piece to the Klan's web of fear and hatred towards the race.

The depictions of African American males interacting with one another in the film are even more negative than those of the males and females. Before the end of slavery in the movie African American males are shown working together in the fields and not causing any problems. After the end of slavery the African American males are allowed to fight in the Civil War and they are shown destroying and burning homes of innocent whites, having large fires in the 
middle of the streets to celebrate, and causing utter chaos. The men are also depicted beating other African American men who are non-supporters of the Union, and even shooting one who will not vote for the Union candidates. The African American males are portrayed as extremely violent and enforcing tyranny about everyone who is against the Union. During one scene the message "The town is given over to the crazed negros" $(B O N, 1915)$ to reinforce the idea that the African Americans are crazy and need to be controlled.

Other scenes in The Birth of a Nation portray African American males as drunks, always sitting around in saloons and drinking and being crazy in the streets together. The Klan during the early twentieth century promoted its self as strong advocate against drinking and saloons. By providing this image of the African American males the Klan could show the audience the disgraceful activities the African American males were partaking in further tarnish their image.

There are several scenes in the film that portray African American males' interaction together that can still be classified as exceedingly stereotypical even today. During one scene a young African American man is shown eating a slice of watermelon larger than his head. He is also one of the actors who are obviously a white male painted black and his lips are made to look as enormous and take up most of his face, engulfing the slice or watermelon. This image, along with fried chicken, that has been used throughout time to portray African Americans although its origin has been arguable, most however link it to the idea that slaves in the South used the watermelon as nourishment due to the lack of water they were given my owners, and that chicken was the cheapest means of meat for poor slaves (authentichistory.com as cited by Kperogi, 2009).

Another stereotypical portrayal of African Americans takes places several times throughout the film, wild dancing. In various scenes the men are shown dancing madly together. They are shown stomping and clapping their hands violently and jumping around while some are playing instruments and others appear to be singing. In comparison to the scenes that depict the whites dancing together in ball gowns and tuxedoes barely moving around the dance floor to violins and cellos, the scenes of the African American men dancing make them look like lunatics.

For many ethnic groups dance is a sign of a ceremonial or traditional way to reconnect with ancestors and relate as a culture (Danesi, 2004). For the African Americans it is a way to remember their roots in African and find a common identity with one another (Cardinal, 1993). The makers of The Birth of a Nation, and the Klan, exploit this deep tradition and bond forming to make the African Americans appear wild and unacceptable. They point out their cultural differences to show how they are completely different from the whites and yet again build upon the web of fear and uncertainty.

\section{Interactions with Whites.}

In the beginning of The Birth of a Nation there are few scenes that show African American women interacting with white women, but all that are shown can be described as peaceful. African American maids are depicted combing young white females' hair and caring for them as if they were their own children. The African American women always appear so happy and pleased to serve the white women they work for. In one scene a white family has been told that their daughter is dead and the African American maid weeps and sobs as if it is her own daughter.

By portraying the African American as so loving and motherly to the white females, the Klan can argue that they enjoy being servants and nannies to the White women and that it pleases them. The whites can justify their enslavement and treatment of the African American 
women by saying they like and even benefit from serving them. The women are never shown being mistreated or abused, and are portrayed as delighted, obedient workers.

The African American women are depicted much the same with young white males as they are with females- motherly and loving. With older white males, not many scenes are shown with them interacting with African American women. The main scene that shows African American women interacting with white males, however, does give an awfully negative portrayal of the woman.

In the scene a white man comes to visit the master of the house and the mulatto maid is shown trying to flirt with him. She pulls her blouse down to show more skin and bats her eyes at him, but he appears to be disgusted and leaves. The mulatto woman is enraged and spits at the man after he has left. She then gets cunning, crazy smile on her face and begins to rip at her clothes and mess her hair all around. She runs to her masters and claims that the man attacked her and her master comforts her.

In terms of white women the Klan could use the film to portray the African American women as dutiful and happy to serve their fellow females. With white men, however, the film portrays the African American women as lustful and deceiving. By providing such contradictory images of the women, the Klan could play to both sides. They could suggest to the White women in audience that while the African American women can help raise their children and take care of their homes, they must beware that African American women will try to steal their men. This was a common portrayal of the African American women as the "Jezebel" character in the media in early American history, and even still today (Brown Givens and Monahan, 2005). This portrayal also suggested that white men are in no way interested in the African American women, as many historical records would suggest. By aiming towards women viewers the Klan could instill fear and resentment on all sides of the spectrum.

The Birth of a Nation aims at portraying all African Americans' relationships with whites very negatively, but especially those of African American males. In a few selected scenes, especially prior to the end of slavery and the Civil War, African American males are shown as respectful and polite to white women. They are more often than not, however, portrayed as lustful, over sexualized and violent creatures who cannot take no for an answer. Even when being respectable, they are shown making crazy lustful eyes at the white females.

The two of the main climactic scenes of the film show the viewer two separate incidences where African American males force themselves onto white women, and portraying the end result is dreadful. In the first of the two scenes, an African American soldier spots a young white woman in the woods and tells her he wants to take a wife and tries to flirt with the lady. She becomes frighten and beings to yell no, then runs away frantically and the soldier begins a hot pursuit of the woman. The African American soldier ultimately chases the white woman to a cliff where she decides it is better to jump to her death than be sexually assaulted by an African American man. After her fall the words on the screen describe her death as an "honor" and a lesson to the white race $(B O N, 1915)$. Through showing the audience that is more respectable to commit suicide as a young woman than to be sexually assaulted by an African American male sends a very strong message of how beastly and revolting the race was to the Klan at this time in society, as well as how necessary it was that the African Americans be controlled and detained. 


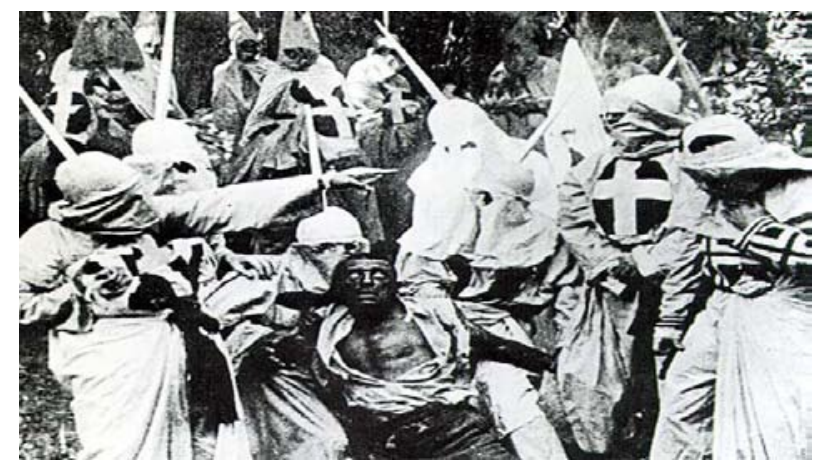

Scene from Birth of a Nation when the soldier is caught after forcing the girl off the cliff (Wordpress.com, 2009)

The second scene that depicts African American males being overtly lustful towards white females is less dramatic than the first, but no less negative and exaggerated. In this scene a mulatto male that is in a powerful government position tells a white woman of an associate he wants to make her the queen of his empire and they will marry. The mulatto man is easily angered at the woman's refusal and begins to chase her around the house until she faints. When she awakes she breaks a window and escapes from the man.

These two scenes send extremely negative messages about African American males. In society during the time of The Birth of a Nation's release, White men presumably felt an urge to protect their women and defend them against anything that may compromise their respectability and womanhood, especially from African American males. As previously stated, one of the biggest protest of the Ku Klux Klan was interracial relationships, regardless if they were mutual or not. The Klan could use these portrayals to great advantage and encourage white, angry men to join them in the defense of their women's honor against what the Klan believed were savage African Americans that were lusting after the women.

The depictions of the African American males with white males throughout The Birth of a Nation are not just as negative of those with white females. Before the end of slavery and the start of the Civil War the African American men are shown being obedient and normally very quiet and sad looking. They bow to the white men and aim to entertain them at times, and always please them. Once the Civil War begins, however, and the African American men are freed and allowed to be soldiers for the Union, they are portrayed much differently. There is only one scene that shows the respectability of the African American men who are labeled "Faithful Souls” $(B O N, 195)$ when they disguise themselves in order to save their white master.

All of the other scenes showing African American males with white males are exceptionally damaging to their image. African American soldiers are shown various times during the scenes involving the Civil War terrorizing white males. They rob and shoot innocent, unarmed white men in the street and on other occasions they pillage and burn their homes. Although these activities may be historically correct and were carried out by Union forces on some Southerners, there are never white soldiers shown in the film shown partaking in these actions. The creators of the film would presumably be suggesting that only African American soldiers terrorized the whites and were unruly and out of control. Through portraying the African American soldiers in this manner the Klan can conceivable convince the audience that African Americans should not be allowed to bear arms or serve in the armed forces; and it can assure the viewers more and more that any African American males - soldier or not- is violent and irrepressible when given any kind of freedom or power over the white man. 
Other depictions of African American males with white males certainly reinforce the notion that the African American males will take full reign over whites if given the chance. In numerous scenes the African American males are seen taunting and harassing white males seemingly just to assert their equality and power over the whites. They threaten white men to stay out of their way and intimidate a white army captain by cornering him and asking "Is I yo' equal cap’n- jes like any white man?” (BON, 1915).

To further implant the fear and resentment of the African American males into the audience, in various scenes they are depicted murdering innocent Klan members and beating the group's sympathizers. It is announced on the screen during one of these scenes that the African Americans want to "crush the white South" (BON, 1915).

With such negative reoccurring images of violence and madness, it would be hard to ask the viewers of the film to think otherwise about the African American males. Their interactions with both white males and females are aggressive and in many cases deadly. They are portrayed as vicious, power and sex hungry, vengeful beasts to encourage the white viewers of the film to take arms with the Klan and protect their people and their home, which in any century are important values to the white culture. The Klan used this desire to protect to create its own culture of not just whites only, but whites who wished to exclude, and in some cases abolish, all other races and cultures different from the one they manifested.

\section{Holding Government Positions}

One of the greatest fears of the Ku Klux Klan in the early twentieth century and throughout time, as well as many other whites, is African Americans holding powerful positions in the American Government. Following the end of slavery and the Union's victory in the Civil War and during the Reconstruction area, some African America males did hold small government role - it was the presumed idea however, that once an African American had any amount of power he would run rampant with it and retaliate against the whites. This fear is greatly played upon in The Birth of a Nation, which offers a suggestion of what was happening, or could have happened, when African Americans were allowed to hold any power roles in America's government.

The film shows an election after the end of the Civil War in which African Americans are permitted to vote. In the scene the African Americans takes over the voting polls and drop in extra votes for the African American candidates and prevent the whites from voting scaring them away from the booth. After the supposed rigged election the African Americans have completely taken over all government positions. A trail is shown with an all African American jury and African American judge, with the man on trial being a white man whose fate would seem to be predetermined by his color with the judge sentences him to prison. The scene shows the few whites sobbing in the court room and the African Americans cheering, portraying the African Americans as vengeful and racists - not whites.

The main scene that depicts African Americans in government positions is introduced with "Master's Hall 1871 Riot” with the Negro Party in control of the House of Representatives with "101 blacks and 23 whites" (BON, 1915). This scene may at first appear humorous to some with the chaos and foolishness that is being depicted, but given the fact that is meant to be a historic representation and portray how African Americans truly act, not be a joke, the scene is extremely degrading and disrespectful to the race.

The African American men are portrayed during the session of The House acting like uncivilized animals. They have their shoes off and dirty, holey socks on with their feet propped up on the table picking their toes, which prompts the leader to order that all men must wear 
shoes, which shows the ridiculousness of the situation. Other men are eating peanuts, which could seemingly imply the monkey or other animal image. One man is shown drinking a bottle of liquor he has hidden in is jacket, and as previously mentioned drinking in any fashion was greatly looked down upon, and drinking while in the government was unthinkable. One African American man is also shown eating a large chicken leg, which reinforces the previously mentioned stereotype of African Americans love watermelon and fried chicken.

Aside from the atrocious activities taking places in this scene that would undoubtedly scare the white audience into never permitting African Americans into the government, the laws that the African American Congress pass would cause utter panic. In addition to the wearing shoes during the meeting rule, the African American law makers pass that all whites must salute negro officers on the street and allow for interracial marriage which is met with cheers from the white in the crowd while the "helpless white minority" $(B O N, 1915)$ hang their heads in disgust.

With the thoughts of such turmoil and chaos taking place among those who are supposed to be leading the country, white viewers would surely jump at the chance to join the white crusaders of the Klan and help keep their country from the crude, vengeful and power hungry fools they depict in The Birth of a Nation.

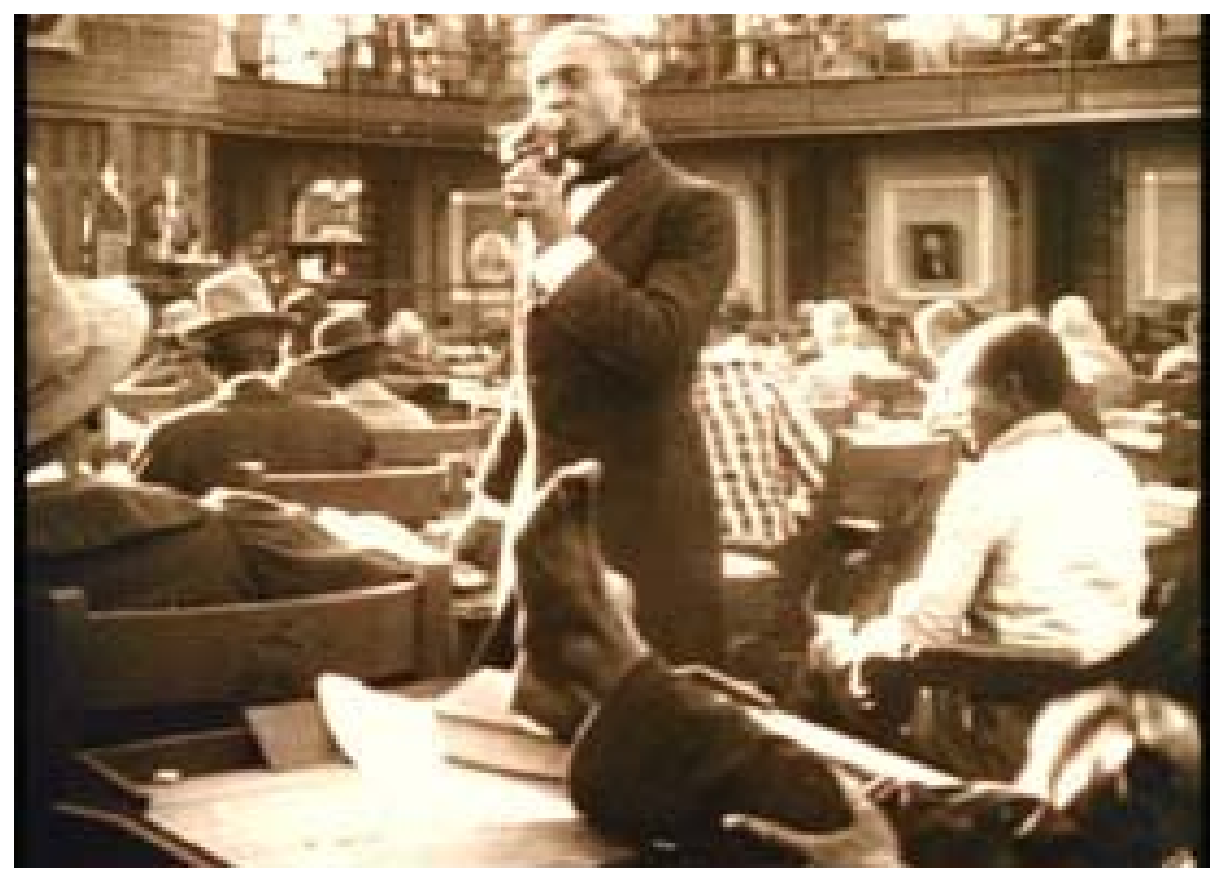

Scene from Birth of a Nation during government meeting. African American male eating a large chicken leg, another with his bare feet propped up on the desk (Wordpress.com, 2009).

\section{Birth of a Nation Summary}

The Birth of a Nation as a whole offers more than enough examples of how horrible and inhuman the African Americans were portrayed by the Klan and their supposed need to be controlled by its forces. The Klan could manipulate the portrayals of the African Americans in any way that best suited its need to embed great fear and hatred into the audience of the film. As previously stated, the film was one of the first ever motion picture experiences for the audience, as well as their first encounter with African Americans on screen. The film painted a highly negative image of African Americans and provides a prime example of Geertz's theory with the 
Klan's weaving of its web to create a culture of white power and hate. The Klan used film to produce an everlasting image of African Americans and establish the term to mean a race that was uncivilized and unworthy of human rights. By spinning a web of how it want the audience to see African Americans, the Klan generated great power through mass media.

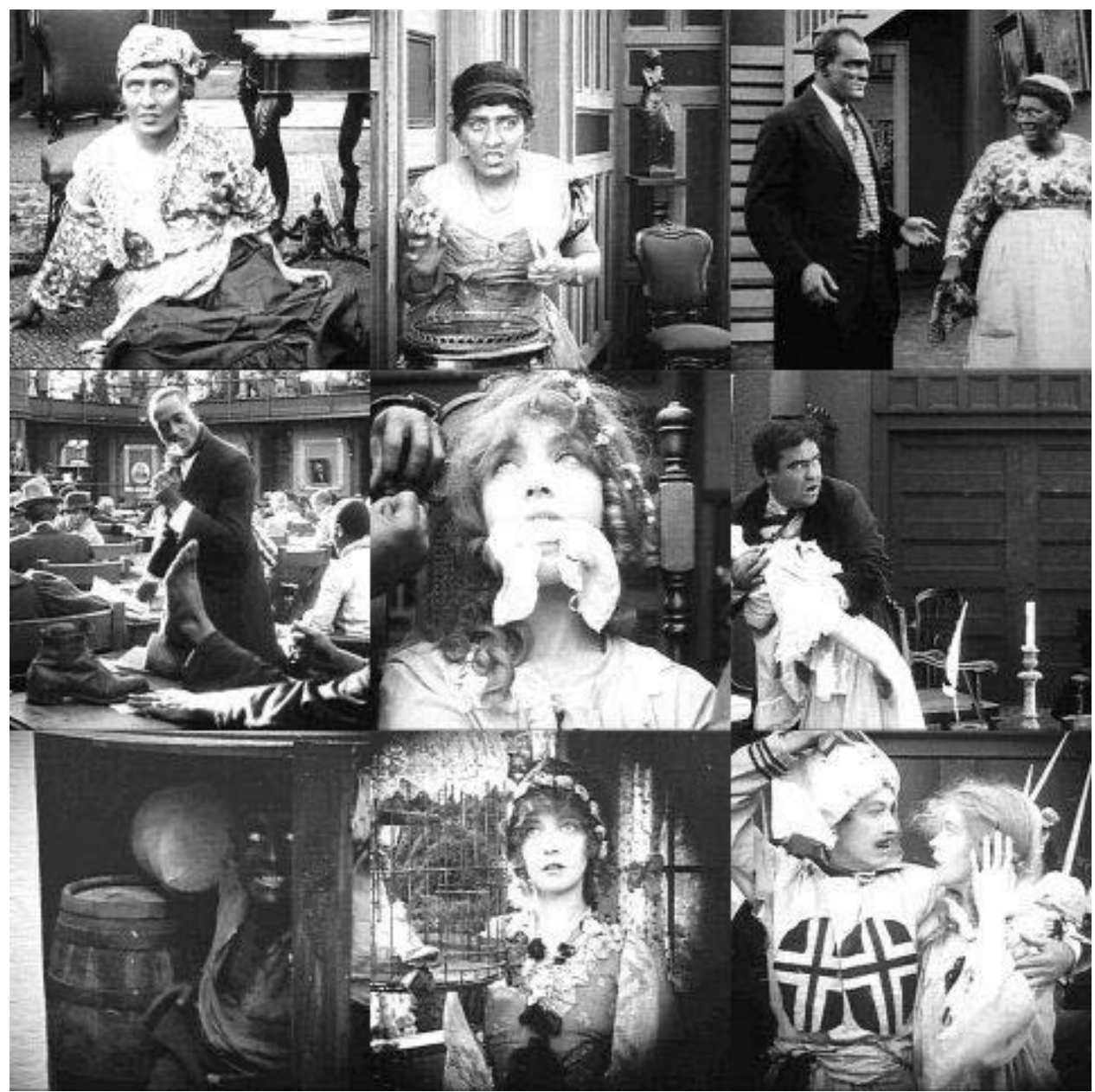

Collage of images from Birth of a Nation. From Left to right and top to bottom: Mulatto housemaid planning to say she was attacked by white male, same maid listening to her master's meeting, African American male wagon driver from the North has a confrontation with an African American female housemaid from the south (both are white actors in blackface), scene from sate house meeting (previously explained), white damsel being silenced by mulatto male, the same two after the white female faints, African American male hiding from a white mob (white actor in blackface), white female considering her love interest, females love interest revealing himself as a Klan member (misbournemedia.com, 2010).

\section{The Toll of Justice}

The second film that was analyzed, The Toll of Justice, did not offer quite as many depictions of African Americans as The Birth of a Nation, but it offered a great insight into the different recruiting tools and themes used by the Klan in early motion pictures. This film is aimed at telling the supposed "true story" (Rice, 2008) of the Klan and defending the bad reputation they were receiving in the early twentieth century, as well as escaping their violent past reputation as murderers and menaces to society . 


\section{Physical Appearance.}

There is only one African American in the film and he is a servant to an older white man. In terms of physical appearance he is dressed like the wagon drivers or male servants in The Birth of a Nation, in a formal tuxedo. He is not a white actor painted dark brown, however, like many were in the previous film. He is also very muscular and larger than nearly all the white men in the film, adding the strength and fear factor.

\section{Intelligence Level.}

Although his role in the plot seems small, the depiction of the African American male character's intelligence level is not left in question of the audience. This film once again portrays the African American male as simple minded, using horrible grammar, and frequently confused. The one scene in which his dialogue is shown the man appears vastly ignorant in speaking to a man that has come to see the daughter of his master. "No sah. Mistah Dale done say caint come in heah Sah" he says (TOJ, 1916). After the white man leaves, the servant says to himself, "Dat fellow was sho' plumb mad” and wildly scratches his head in confusion, which he is shown doing various times throughout the film.

Although there are no words or even music in the film and very few whites' dialogue is shown on the screen, the creators of the film made it a point to display the one African American in the films way of speaking. The fact that it was included at all shows the negative mindset towards the African Americans that the Klan had, and even though this film was aimed at cleaning up their image, the organization did not leave out their views of the race.

\section{Interactions with Whites.}

There are no scenes where the African American character interacts with other male or female African Americans and none where he is interacting with white females either. He is only seen by himself tending to things in his master's house or with his master or other white males. When interacting with his master the African American is always shown as obedient and pleased to serve, as the servants were in The Birth of a Nation.

In one of the main scenes that the African American character is shown with other whites takes place when he is sent on an errand. He is walking through the woods when he spots what he thinks are Klan members, but really men who stole a Klan robe and hood. The white men jump out at the African American and he drops his bags with fear all over his face and begins to run. Once out of sight the men take of the hoods and laugh hysterically at the man running away. This scene can serve two purposes for the Klan. First, to show that the "real Klan" does not scare and intimidate African Americans, only imposters who have stolen their outfits do this to try and give them a bad name. Secondly, this scene can show that the African Americans are in fact extremely frightened by the Klan, and this can be used to their advantage.

\section{The Toll of Justice Summary}

Despite the fact there is a small presence of African Americans in The Toll of Justice, the depictions that are given portray the race in an overtly negative manner. The only African American in the film is large and scary looking, but appears to have an exceedingly low intelligence level. He is compliant and pleases his maters as he is expected to, putting forth that this is how all African Americans should behave, regardless of the fact that slavery has been over for decades. Although this film is said to intend to clear the name of the Klan from acts it protest that it did not partake it in, the film still shows the group's true beliefs concerning African Americans and builds upon the idea that they need to be kept under the rule of whites and continues spinning the web of hatred and terror that the organization created from its beginning. 
In one of the final scenes the Klan is shown having a meeting with hundreds of hooded figures coming down from all sides of the small mountain. As the group is coming together a young white girl runs to the middle of the circle and it is flashed on the screen why they are meeting, "The appeal which stirs every man to vow allegiance to this brave little girl and help bring criminals to JUSTICE” (TOJ, 1916). However, “criminal” and “justice” are terms defined in a different manner by the Klan than that of others in society.

\section{Films' Summary and Conclusion}

The films that were analyzed in this study, The Birth of a nation and The Toll of Justice, both offer depictions that are degrading and damaging to the image and likeness of African Americans in the early twentieth century. The race, both male and female, is portrayed as violent, unintelligent, and out of control. The films show the audience that if allowed the chance of free will and power African Americans will take over the nation and seek revenge on whites. Many images, especially in The Birth of a Nation, portray the males as lustful, power hungry beasts that will ravish white women and murder any white man in their path to power and respect.

These types of portrayals were easily embedded into the minds' of white audience that were seeing a motion picture for the some of the first instances in history. The Ku Klux Klan easily manipulates the viewers' already present fears of outsiders. The films both help the Klan point the finger at whom to blame for the present problems in society and throughout American culture and provide lasting, unpleasant images of African Americans.

Although the Klan blatantly shows its hatred and racism in The Birth of a Nation, giving an obvious impression on the audience, The Toll of Justice, however, is more subtle with its message of racism and degradation of African Americans. This type of almost hidden implications in The Toll of Justice, although probably accidental on the film maker's part, could presumably be just as affective on the audience as the open stereotypes and racism in Birth of $a$ Nation. The embedding of subtle racist images of African Americans may work their way into the mind of the view and manifest in their mind even longer than the outright hatred and discrimination presented in the Birth of a Nation due to the fact that it seems less offensive and accepted by all members of society.

The image of a large African American male as a dutiful servant to whites may at first glance appear as an unimportant and harmless portrayal, but it the view later fits every African American male into this category and expects all African Americans to serve and cater to whites, the image given by the film seems highly dangerous. With the portrayals and messages presented in both of the films analyzed in this study, whether using explicit hatred and racism or not, it quite apparent that films of the early twentieth century could have aided the Klan significantly in producing its mass web that entangled its members and entrenched them in the culture of white supremacy and degradation of African Americans.

\section{Websites}

\section{www.kkk.com}

The first website that was analyzed in the study was www.kkk.com which leads to www.kkk.bz. This site boasts that it is the "Official Website of the Knights Party, USA" (kkk.com, 2010). The site offered a lot of different possibilities to the viewer and used various techniques to pull the visitor in. There was a song playing with young women singing about their allegiance to the Aryan Nation and many colorful photos, numerous links to blogs, videos, 
articles, and different sections catered to kids, women, and parents. This site seemed to aim at appearing nonracist against African Americans, but in their terms- preserving the white heritage.

\section{Intelligence Level.}

This site portrayed African Americans as vastly less intelligent as whites both in the past and in present time. The site offers many quotes to prove this point: "His brain capacity is poorer" (1931, referring to the African American), "The Negro is mentally inferior to the white" (Manett), "The Negro would appear to stand on a lower evolutionary plane that the white man" (Encyclopedia, $11^{\text {th }}$ Ed.). The site also suggests that biologically African Americans' brains are smaller, stating that a white man's brain is 45 ounces and an African American's brain is 35 ounces and has less frontal left lobe (kkk.com, 2010). The website does not blatantly say that African Americans are stupid, but it certainly asserts that they are nowhere close to the intelligence level of the white man.

In addition to being less intelligent than whites, the site advocates that African Americans, among other races excluding whites, have no respect for human life. It states that, "no one is more compassionate and cares more about the environment and nature than the white man's” (kkk.com, 2010). These assertions portray African Americans as heartless creatures with no regard to other human beings or anyone or anything on earth. The Klan can undoubtedly use these so called facts to justify their promotion of the white race and cause great animosity in viewers of the site towards African Americans. It presumably would be difficult to feel sympathy for anyone believed to not have any concern for other humans.

\section{Interactions with Members of Their Own Race.}

This website claims that nonwhites will always stand together in opposition to whites. Although it does not offer any exact examples of how this is so or instances with African Americans interacting with one another in this manner, it makes many negative allegations about revered African Americans and the ideas surrounding them in the African American culture. The site puts forth that Martin Luther King Jr. was a "race-mixing Communist” and "anti-Christian agitator," as well as a sexual pervert (kkk.com 2010). The site claims that King was caught on more than one occasion with white prostitutes and forced himself on a white civil rights activist. The creators of the site want the holiday celebrating his birthday abolished, because they feel he does not deserve the nation's respect.

Through making such strong accusations about such an honored and respected person in the African American community, as well as by many whites, the Klan insults the entire African American heritage and anyone who ever fought for civil rights a mockery. The site portrays one of biggest heroes in African American culture and history as a sex-crazed liar. This not only reflects badly on King, but the whole race. Those already against African Americans, for any reason can read these accusations and even though the website provides no source for them, completely believe every word and this will fuel the individuals' hatred of the race even further.

An additional report that this website made related to African Americans' interactions with one another is that "the AIDS virus is almost inclusive to homosexuals and those not of European decent” (kkk.com, 2010). Although this statement does not directly address African Americans, can certainly be linked to them especially when other remarks under different links on the site do specifically mention African Americans. The site avows that more than half of the children with the AIDS virus are black, and calls the disease the "Black Plague" (kkk.com, 2010). Again, the site offers no source for these assertions, but it can be assumed that just by saying they read it on the Internet, many people will believe these things to be $100 \%$ true. AIDS is a horrible disease that most people do not fully understand and has caused much controversy. 
When something as contentious as race is with the Klan it only fuels the fire of fear and hatred to add into the mix another factor as controversial and terrifying as AIDS, and the Klan and/or the creators of this site are unquestionably aware of this idea and use it to their advantage.

\section{Interactions with Whites.}

On the website kkk.com there were several accounts of how African Americans have gone against whites and harmed their status in America. The website states numerous times about incidents of African Americans committing crimes against whites and claims that African Americans commit $90 \%$ of the approximately 1.7 million interracial crimes a year. The site goes on to say that many white people are the victims of hate crime. It also suggests that a white kid in a mostly black school is an easy target for "hate filled Negros" and blame the public schools for creating "angry and violent Negros" by teaching them "evil stories about the white man!" (kkk.com, 2010).

This website also strongly protests Affirmative Action saying that is take jobs away from deserving whites. It portrays African Americans as unqualified and undeserving. They say that most African Americans are only in the jobs they have because someone needed to fill a quota of minorities in a company.

Much like the two films this site does well to instill the fear in the visitors and warning them against African American men preying on their white women. It avows that race mixing is a sin. The site goes as far as saying the Disney Channel is an abomination for airing shows that promote race mixing, such as "Sister, Sister” and “That's so Raven.” It protests that children who watch these shows will be believe it acceptable to date and/or marry interracial, something the Klan, and the website, is strongly against. The website states that white women only date African American men because they are too compassionate and do not want to appear racist, while white men date African American women because they come across as exotic.

These negative statements portray African American men as undeserving of white women's love and African American women merely as sex objects, both of which were seen in the films. Even after almost 100 years, the Klan still stays strong to its affirmation that blacks and whites should not mix, and white men need to protect their women. The same web of fear and resentment is being spun; it's just a different means of spinning.

\section{Holding Government Positions.}

With the fact that the United States elected an African American president the website took full advantage of pointing out the atrocities that Barak Obama is guilty of. The site portrayed President Obama as a traitor to his nation, saying he has an allegiance to Africa and he will use money intended for American/white children to Africa. It also states that the President has alliances with Israel and is letting Jews take over the American government, and that Obama is loved by the Communist Party.

This website calls the present time America's “darkest hour” because they have elected a "Negro president" (kkk.com, 2010). It portrays President Obama - much like the films portrayed the blacks in the government during Reconstruction - power hungry and determined to overthrow the white race. The website points out that Obama is involved in a "race war -- a culture war -- against white people” and that the government betrayed the white race by putting "power in the hands of Negros" (kkk.com,2010).

It is comments such as these that portray the President of the United States as a terrorist that wants to destroy American and every white in that lead to a reported record on gun sales and convinced many Americans that Obama is a black supremacist (Carrington, 2009). By providing a specific person to direct the fear and hatred toward the Klan and creators of this sight can use 
President Obama as a target and example of all African Americans and generate this idea that the race is trying to take over the country. In the aftermath of September 11, 200, many Americans are severely afraid of anyone who is of non-European decent and believe them to have terrorist potential. White supremacy groups, such as the Klan, use this fear to add to their own power and persuade people to join then against the dangers outsiders who are trying to take over their country and destroy their race. With Internet, they are able to reach a much wider demographic and spin a larger web than ever before.

\section{www.kkk.com Summary}

The results of this website indicated that the Klan is still concerned with many of the same issues in the twenty-first century as it was in the twentieth at the time of the films' releases. This site aimed at encouraging the preservation of the American heritage, which it asserts is white heritage, by controlling African Americans and stopping them from committing hate crimes, protesting race-mixing, and keeping the power of the government in the hands of the white race. It painted an overall picture of African Americans as violent, disease ridden, white haters, but insists that it is not racist, and all while playing catchy music.

\section{www.kkkk.net}

The second Internet site that was analyzed in the study, the site for the Imperial Klans of America, was much more offensive in their portrayals of African Americans and open with their hatred for the race. There are a few song links, YouTube videos, and links for various state based Klan websites. There are also link announcing festivals, concerts, and events with games and food in support of the IKA.

The site made no specific mention of African Americans' physical appearance or intelligence level, but this did not take away from its evident loathing of the race. The site states the IKA "hates: Muds, spics, kikes, and niggers" and asserts that this is their "God given right!" They warn that "If you are not of the white race, this website is not for the likes of you" (IKA, 2009).

\section{Interactions with Members of Their Own Race.}

This website makes several references to incidents involving African Americans that can portray them as negatively as possible. There is a link for an article on African Americans' behavior in New Orleans, after Katrina. The article says that they shot rescuers, robbed businesses and homes, did carjacking, numerous rapes in the Super Dome, were smoking crack, and even claims that some were eating corpses. These statements provide no reliable source of and portray African Americans as violent, drug users, rapists, and even cannibals. Whether these reports are embellished or not would matter not to the reader. Even without a literal picture the Klan paints a very clear image of how disgusting and threatening it sees African Americans to be, and this is an image that will last in the sites’ visitors' minds for a very long time.

\section{Interactions with Whites.}

An article under the link "lawless nonwhites" (IKA, 2009) provides even further opportunities to spread fear and hatred of African Americans, and this time it is much like the films and previously mentioned website in appealing the need to protect white women. The article presents a mug shot and the name of an alleged African American rapist and murder. With the headline "Nigger Kills White Woman" the article states that the man accused admits that "as 
long as she has blond hair and blue eyes, she had to die” (IKA, 2009). Although the website provides some specific people of interest in crimes, with such horrid words given and messages offered it would be presumably difficult for visitors to make generalization of the entire race.

Just like the two films and the previous website, the IKA site makes a grand protest against interracial relationships, calling them an "abomination of God" and a "worse sin than murder” (IKA, 2009). You must vow to never have been involved in an interracial relationship and believe in racial segregation in order to become a member of the organization. If being accused of committing a bigger sinner than a murderer and being destined for damnation wasn't enough to scare whites away from race mixing, the site also proposes with a fake court case that in the year 2100 Congress will pass a law making it illegal for two full blooded whites to conceive a child.

\section{Holding Government Positions.}

This particular site did not offer a large amount of protest against African Americans in America's government but provides on video on President Obama. The man on the video suggests that Obama is a leftist liberal wants to abolish free speech with his hate crimes bills. He states that Obama is brain washing children by implementing new education that teaches against homophobic views and other hate related issues and crimes. Although the IKA site does not provide a lot material on its views of an African American having power over the country, its disapproval and aversion toward the President is quite obvious.

\section{www.kkkk.net Summary}

By means of such outlandish ideas, the Klan does not put the fear of God into whites so to speak, but the fear of the African American and equates the race with all that is wrong in the United States. The propose whites to be the divine race and ruler of the world. With each proposed idea and exaggeratedly negative portrayal, the Klan continues to contrive this notion that all African Americans are sadistic, beastly creatures. The Klan can carry the image further and further with the help of the Internet, which the creators of the site even state their knowledge of this fact saying, "With the advent of the Internet and other technologies, we now have a serious advantage. If a young white is curious all they have to do is type a few words into a search engine and they are introduced to the entire world of white power” (IKA, 2009). The IKA, and presumably all branches of the Ku Klux Klan, are well aware of the power the Internet provides them in forming a society of white supremacy and hate.

\section{Websites Conclusion}

Though the two websites analyzed were set up a little differently and offered distinct features and ideas, they carried mostly the same themes and portrayals. Both warn against interracial relationships and portray African Americans, especially males, as excessively sexual and lusting after white women. Both websites also make reference to the current political situation with an African American in power over the country and make specific reference to President Obama. They state that African Americans are greedy and power hunger and they will abolish the white race.

As with the two films that were analyzed in the study, the two websites offer two different techniques of spreading their white supremacy message. The first website, kkk.com, is was found to be less offensive or overtly racist. They seem to aim a more respectful and Godly message that promotes white pride and more subtly suggesting that African Americans are below whites and need to be controlled. The second website, kkkk.net, was extremely racist and had several instances if offensive language and material. Although this site spoke out against 
violence, it seemed to suggest it in many ways and provide more than enough degrading images of African Americans in order to promote white supremacy.

As previously mentioned about the films, the website that offers the less obvious and offensive approach to white supremacy could presumably be more affective on the visitor and have a longer lasting affect than the highly racist and provocative website. The kkkk.net, offers more shock value and strong words against African Americans that could indeed persuade visitors of the website to join the Klan or spread it message. The other website, kkk.com, however, offers a more acceptable and less-forceful approach that may appeal to those who wish to go by the motto that they are not racist or against African Americans, they are merely promoting their own race and white pride. This way of describing white supremacy may sound more respectable and offensive, but it is just as degrading and dangerous as the more openly racist and aggressive message of the Klan.

The two websites certainly both do their best to spin a web of terror and hatred playing off already present fears in white Americans to create their own reality of a culture filled with white pride and power. They take different approaches to spreading their message against African Americans and other minorities, yet their ideologies are still just as hate filled and demeaning as the others'.

\section{Chapter V: Summary and Conclusion}

Through the analysis of The Birth of Nation, The Toll of Justice, and the two websites, it was found that there were numerous similarities and several differences in the portrayal of African Americans from the twentieth century in films and the twenty-first century on the Internet used by the Ku Klux Klan. The similarities and differences can be attributed to the cultural and society dissimilarity and likenesses of the two centuries, as well as those in the media used. The significant parallels and differences are as follows:

\section{Prime Differences}

One of the most notable differences found in this study in the portrayal of African Americans between the films and the websites was the amount of emphasis that was placed on portraying the race as insane or crazy. This greater emphasis in the films may have also come from the fact that this film also put a great deal of effort into making a bold statement about the considerable difference in physical appearance of African Americans than that of whites. While The Toll of Justice and the two website rarely pointed out this issue. The films, again especially The Birth of a Nation, intensely portrayed the race as crazy by using exaggerated facial features and expressions, including bulging wild eyes, and cunning smiles with large protruding lips.

It can be concluded that the main reason that differences exists between the one film and the websites, is due to the fact that the makers of the film were creating one of the first featurelength films and were excited to literally show the audience how unlike the whites they believed the African Americans were. As previously mentioned, in the early twentieth century many whites were angered and frightened by immigrants coming into America. Also at this time, African Americans were not as large a percentage of the population as they are today and presumably not everyone had been acquainted as closely with the race, therefore it was easier to construct a literal image for the white audience to remember and fear. In the twenty-first century, even in the most rural of areas it would be hard to find someone who has never seen an African American, even if just on television and this makes it harder to embellish their physical appearance and produce a different image than what most people have already seen. 
An additional difference that was noteworthy between the portrayals of African Americans in the films verses the websites was that in The Birth of a Nation African American women were depicted quite frequently as care givers to white children and/or lusting after white men. The two portrayals offered in the film were either the stereotypical "Aunt Jemima” character or the tramp after the white man's sex known as the "Jezebel" characters that were previously mentioned. In The Toll of Justice, however, no African American women are never shown, and there is also very little mention of them on the two websites. The websites focus mainly on African American males.

The most fathomable suggestion that can be made to explain this difference in the frequency in whish African American females are shown, is that in the early twentieth century many white men had been accused of having sexual relationship with African American woman slaves, and in order to defend this accusation the Klan wished to show that it was the African American women who were lusting after the white males, not the other way around. In the current American society there does not seem to be the same fear that African American women are seducing or staking out white men, but more so that African American men are still seeking out white women and this fear is more focused upon in the websites.

In The Birth of a Nation African Americans were also portrayed as avid drinkers. In several scenes African American men, and even in one scene an African American women, are shown getting drunk, either in a bar or at a gathering on the street. On the websites that were analyzed, however, this was never mentioned once. The prime explanation for this change in portrayal can be attributed to the truth that alcohol consumption does not seem to be as big a stigma in the twenty-first century as it was in the early twentieth century. Although there may be some that are still strongly against drinking, the Klan of the current time seems to have more important battles to fight and issues to address than shutting down a local bar. Americans have created a culture that used alcohol to celebrate nearly every occasion regardless of race.

A notable change that was found in the portrayal of African Americans on the reviewed websites that did not exist in the films was that the websites reference specific, factual African Americans when addressing an issue, while the films used fictional people. Both website mention current President Obama when discussing the turmoil of the government under African Americans and one website also reference African American icons such as Martin Luther King Jr. and Marcus Garvey in order to make negative portrayals and generalizations about the race. One of the websites also offers actually names and photos of African American criminals.

This variation in reference of African Americans can mainly be accredited to the fact that there were not many currently famous African American heroes or activists to reference at the time of The Birth of a Nation's or The Toll of Justice's making or perhaps the Klan wished to give a more general overview of the atrocities that African Americans had created more than point fingers at certain individuals. An additional explanation for this change is that the Internet in the twenty-first century can offer any link to any person the user wishes to find. If the Klan makes a reference to someone in the African American community, chances are there will be another website that can tell the user all about this person if they are not already familiar with them. In the time of the twentieth century many whites were uneducated and in rural areas many may not have known references to specific African Americans. The extent of information was not as readily available during that time as it is in the current American culture. 


\section{The Threads that Completes the Web}

There were several portrayals of African Americans and themes surrounding them that existed both in The Birth of a Nation and all four of the Internet sites that were analyzed in the study. The first one that was most prominent was the portrayal of African American males as violent, angry and wild creatures - sometimes even animals - that are predestined to commit vicious crimes. Although this image was depicted in different manners, the message was always the same.

The second significant similarity found in Birth of a Nation and the two Internet sites was the warning against interracial relationships and portrayal of African American men as sexual predators of white women. The defense of white women's sexuality and honor was a prime objective of the Klan obviously in both the twentieth and the twenty-first century. The Birth of a Nation depicted this issue in the worst way by suggesting that it was more honorable for a white women to commit suicide than be had be a lustful African American man. All four websites also stated that interracial relationship were an abomination and would destroy the white race. One even called it a worse sin than murder.

An additional depiction that was found in the films and both websites was the issue of power in the hands of African Americans. The websites made reference to political power, but politics aside, the websites and The Birth of a Nation all portrayed African Americans as power hungry and vengeful. Both mediums suggest that if given any control or inkling of power, African American will seek retaliation and unite to abolish the white race. In The Birth of a Nation this is shown in exaggerated, mostly fictional terms with the all "black majority" and the depiction of the turmoil that African American soldiers and government leaders bring to the nation. On the Internet sites reference is made to the supposed horrid condition of America attributing to the government, which happens to be run by an African American. Whether fictionalized or backed by fact, the Klan strongly continues to push the image of its belief of the dire consequences if African Americans are allotted power over whites or even if given equality.

All of these similarities that were discovered in how the Klan has portrayed African Americans in both the twentieth and twenty-first centuries to promote and justify the organization can be ascribed to a simply a few tactics and reasons within society. Regardless of the time period, American culture will always be opposed to change, especially when it involves drastic, negative circumstances. The Klan has used this fact against society for years and feed of their already present fears of what is different and unknown. It has used new technology in each century to take this fear to higher levels.

Although this study is unique in examining how the Klan has portrayed African Americans in two different types of mass media, some of the finding of the study do concern with previous research on the Klan's use of media. The analysis of the two films in this study suggested much like Rice's study on the Klan and the film industry (2008) that while the Birth of a Nation presented a more violent and dehumanizing image of the Klan, The Toll of Justice was more concerned with provided a cleaner and more respectable representation. As Rice (2008) proposed the Klan used the latter film in effort to appear more acceptable in society.

In terms of the finding within the websites, just as Palmer and Duffy (200), as well as Weatherby and Scroggins (2005), concluded from their studies on hate group websites, the one website analyzed in this study stayed away from racial epithets and blatant racism. The kkk.com website used in this study was found to be much like those reviewed in the before mentioned studies. It aimed at showing a more acceptable way of showing white pride, while trying not to seem degrading to African Americans. The two previously mentioned studies also found that 
most hate group websites proposed what the site said were facts and tried to appear scholarly and well-researched. The website evaluated in this study also provided several instances of this tactic.

As Charles Mills (1997) suggests, there has always been a type of unwritten "racial contract" that has existed in the world, more importantly in America. From the founding of this nation up until present time, Western culture has based on the morals and ethics of white Europeans and excluding all non-whites, including African Americans, thus removing them from the level of whites and allowing them to receive immoral and unethical treatment. Mill uses a quote from author James Baldwin to point out that media, and society in general, has "allowed white people, with scarcely any pangs of conscience whatever, to create in every generation, only the Negro they wished to see” (Baldwin, as cited by Mills, 1997, p. 88). In applying this idea to the Klan, it has created the African American that is a menace and stain on American society that must be rubbed out.

The results and conclusions of this study are a prime example of Geertz's cultural approach to organizations theory and semiotics working in perfect harmony. The films of the twentieth century and the websites of the current time period both place the Klan and white America at the center of the web. The Klan then perpetuates and creates stereotypes and generalizations to establish a reality - a culture - in which African Americans are the outmost enemy. The Klan uses ignorance and fear to place meaning to different aspects of African Americans' lives that may or not be true. The Klan uses the mass media in both centuries to make African Americans a symbol for crime, disease, corruption, greed, and all peril that white Americans face.

As Mars (2008) suggests in using CAOT, if you know how a group is organized you can allocate its values, attitudes, and the types of behaviors it justifies. The Klan is a group organized by power, fear, and white divinity. These aspects make the group place high value on loyalty to the organization and the white race. These values then help to justify its ideals and treatment of African Americans, placing them below the Klan and anyone without white skin.

The findings of this study would suggests that despite many claims that American society has taken great strides in accepting minorities and making changes that some aspects of our culture never change. Humans will always be afraid of losing power over their own lives, including their land, their family, their jobs and money, and even their respect as human being. This fear is especially strong when the loss may be caused by someone presumed to be less deserving than them. The Ku Klux Klan has continued to spin the same web for centuries to build a white supremacist culture based on fear and power. It has moved from print, to film, and in current time to the Internet, which in itself spins a web of reality created by the user connecting anything he or she wishes, and in the Klan's case a world wide web of hatred and discrimination against African Americans and other minorities.

\section{Chapter VI: Closing Thoughts and Recommendations}

Society is forever changing and growing and new subcultures develop nearly every day. This study has sought to identify the changes that have taken place within the culture of the Ku Klux Klan and its portrayals of African Americans in two very different technological advances in mass media. As Geertz (1973) points out, culture is a not a power - something that the aspects of society can be contributed to - but it is something in which these aspects can be comprehensibly described. This statement would imply that the portrayals of African Americans given by the Klan are not simply products of the Klan's or America's culture, but they expose 
how the culture works and the meanings behind it. One piece cannot be looked at without considering the whole culture, and the whole culture cannot be defined without considering each piece.

There are many possibilities that can be drawn upon from the results of this study; just it has drawn upon previous studies. As mentioned earlier, things in society are constantly changing; this same study could be conducted even a few years from now with the same websites and undoubtedly yield new results. A further suggestion could be using more recent movies that depict the Klan or other white supremacy groups, such as Mississippi Burning, and American History $X$ and analyze the depictions of African Americans in these films verses those of the twentieth century. In keeping with the theme of new technology, an interesting study may be how African Americans are portrayed by users on MySpace and/or Face book and if any Klan organizations use these networks. All these ideas, including this study can also be reworked to any minority group of the researcher's choice. There are truly infinite possibilities in the world of mass media and today's ever growing world of technology.

The mass media and technology are extremely powerful tools and must be used wisely. It would be naive to suggest the findings of this study, or any one study, could end the use of negative portrayals of African Americans and stereotypes in the mass media. It would be even more profound to think that it could end racism and hatred towards African Americans or any minority group. This task was not the goal of this study. Its purpose was simply to identify what, if any, changes the Klan has made in its use of images of African Americans to recruit and keep the organization alive, and why or why not changes have been made. It is, however, the hope of the researcher that the results of this study can at least aid in understanding why the Klan is still successful in its perpetuation of stereotypes and negative images of African Americans and thus take a small step towards trying to limit its success. 


\section{References}

Adams, J. (2005). White Supremacists, Oppositional Culture and the World Wide Web. Social Forces, 84 (2) 759-778.

Altheide, D. (1996). Qualitative Media Analysis. Thousand Oaks: Sage Publications.

Authentic History (2009). "Stereotypes of African Americans: Chicken and Watermelon Themes.”

http://www.authentichistory.com/diversity/african/chickenwatermelon/index.html

Berry, J. (2009). “American Knights of the Ku Klux Klan.” Retrieved December 5, 2009 from www.kukluxklan.info/presents/americanknights/index.htm

Billig, M. (2001). "Humor and Hatred: the racist jokes of the Ku Klux Klan.” Discourse and Society, 12(3), 267-289.

Blazak, R. (2001). White Boys to Terrorist Men.” The American Behavioral Scientist, 44(6), 982-1000.

Bostdorf, D. (2004). "The Internet Rhetoric of the Ku Klux Klan” A Case study of Web Site Community Building Run Amok.” Communication Studies, 55(2), 340-361.

Brown Givens, S., \& Monahan, J. (2005). "Priming Mammies, Jezebels, and Other Controlling Images: An Examination of the Influence of Mediated Stereotypes on Perceptions of an African American Woman.” Media Psychology, 7(1), 87-106.

Brummel, B. (1998). The Ku Klux Klan: A Secret History. New York: A\&E Television Networks.

Cardinal, M. (1993). "African rhythms and their implications for the American jazz dance class.” Impulse: International Journal of Dance Science, Medicine \& Education, 1(1), 39-51.

Cavalier Motion Picture Company (Producer). (1923). The Toll of Justice [Motion Picture]. United States of America.

Chalmers, D. (2003). Backfire: How the Ku Klux Klan Helped the Civil Rights Movement. Lanham: Rowan \& Littlefield Publishers, INC.

Donahue, E. (2008) “Police: Woman Killed during KKK Initiation.” Associated Press.

Fang, I. (2008). Alphabet to Interne: Mediated Communication in our Lives. St. Paul: Rada Press Inc. 
Frith, S. (1996). "Music and Identity.” In Questions of Cultural Identity. Ed. Stuart Hall and Paul du Gay. London: Sage Publications.

Geertz, C. (1973). Interpretation of Cultures. New York: Basic Books Inc.

Gerlach, L. (1992). "A Battle of Empires: The Klan in Salt Lake City." In The Invisible Empire in the West: Toward a New Historical Appraisal of the Ku Klux Klan of the 1920s. Ed. Shawn Lay. Urbana: University of Illinois Press.

Gernstenfeld, P., Grant, D., and Chiang, C. (2003). "Hate online: A content analysis of extremists Internet sites.” Analyses of Social Issues and Public Policy, 3(1), 29-43.

Griffith, D.W. (Producer). (1915/1993). Birth of a Nation [Motion Picture]. : Kino on Video: United States of America.

Hansen, A. Cottle, S. Negrine, R. and Newbold, C. (1998). Mass Communication Research Methods. New York: New York University Press.

Kperogi, F. (2009). “Fried chicken and watermelon: Racism through food in America.” Weekly Trust.

Lay, S. ed. (2004). The Invisible Empire in the West: Toward a new Historical Appraisal of the $\mathrm{Ku}$ Klux Klan of the 1920s. Chicago: University of Illinois Press.

Levin, J. and McDevitt, J. (1993). Hate Crimes: The rising tide of bigotry and bloodshed. New York: Plenum.

Mars, G. (2008). "Corporate cultures and the use of space: an approach from Cultural Theory.” Innovation: the European Journal of Social Science Research, 21 (3), 185-204.

MacLean, N. (1994). Behind the Mask of Chivalry: The Making of the Second Ku Klux Klan. New York: Oxford University Press.

http://misbournemedia.com/comshomework.htm (2010).

Nightingale, V. (1996). . Studying Audiences: The shock of the real. London: Routledge.

Palmer, V. and Duffy, M. (2001). "The Reality of Virtual Hate: A fantasy Theme Analysis of the Rhetorical Vision of Hate Groups Online.” Missouri Journalism Library, 1-26.

Palti, L. (2005) “Measuring Hate.” Washington Post. Washington D.C.: Newsweek Interactive, LLC.

Rice, T. (2008) "Protecting Protestantism: The Ku Klux Klan vs. The Motion Picture Industry.” Film History, 20 (3), 367-380. 
Rice, T. (2008). “'The True Story if the Ku Klux Klan’: Defining the Klan through film.” Journal of American Studies, 42(3), 471-488).

Richardson, R. (2002). "The Birth of a Nation'hood": Lessons from Thomas Dixon and D.W. Griffith to William Bradford Huie and The Klansman, O.J. Simpson's First Movie. Mississippi Quarterly, 56 (1), 3-32.

Southern Poverty Law Center (2009). “Intelligence Project.” Retrieved December 5, 2009 from http://www.splcenter.org/intel/map/hate.jsp

The Knights Party, USA (2009). Retrieved December 5, 2009 from http://www.kkk.com/

The Imperial Klans of American. (2009). Retrieved December 5, 2009 from http://www.kkkk.net/

The Toll of Justice (1916). [Motion Picture] United States of America.

United Northern and Southern Knights of the Ku Klux Klan (2009). Retrieved December 5, 2009 from http://www.unskkkk.com/

Wade, W.C, (1987). The Fiery Cross. London: Simon \& Schuster Ltd.

Weatherby, G. and Scroggins B. ( 2006). "A Content Analysis of Persuasion Techniques Used on White Supremacist Websites.” Journal of Hate Studies, 4 (1), 9-31.

Wilson, C II. Gutierrez, F., and Chao, L. (2003). Racism, Sexism, and the Media: The Rise of Class Communication in Multicultural America. Thousand Oaks: Sage Publications, Inc.

Wordpress.com “American Civilization.” (2009). http://amciv.wordpress.com/2009/02/18/racing-science/ 
Appendix A

Film Analysis Code Sheet 


\section{Portrayals of African Americans in Films used by the KKK}

Movie Title: Year Released:

Date viewed:

Males’ interactions with males of their own race: 
Males' interactions with females of their own race: 
Males' interactions with White males: 
Males' interactions with White females: 
Females' interactions with females of their own race: 
Females' interactions with White females: 
Males holding government positions: 
Males’ intelligence level: 
Females’ intelligence level: 
Females’ physical appearance: 
Males’ physical appearance: 
Other observations: : 
Appendix B

Analysis of Websites Code Sheet 


\section{Portrayals of African Americans Websites used by the KKK}

Website Address:

Date viewed:

Males' interactions with males of their own race: 
Males’ interactions with females of their own race: 
Males’ interactions with White males: 
Males' interactions with White females: 
Females' interactions with females of their own race: 
Females' interactions with White females: 
Males holding government positions: 
Males’ intelligence level: 
Females’ intelligence level: 
Males’ physical appearance: 
Females’ physical appearance: 
Other Observations:

\footnotetext{
John H Virginia University Libraries, 